10-1982

\title{
Papyrology and Roman History: 1956-1980
}

James G. Keenan

Loyola University Chicago, jkeenan@luc.edu

Follow this and additional works at: https://ecommons.luc.edu/classicalstudies_facpubs

\section{Recommended Citation}

Keenan, JG. "Papyrology and Roman History: 1956-1980" in Classical World 76(1), 1982. 23-31.

This Article is brought to you for free and open access by the Faculty Publications and Other Works by Department at Loyola eCommons. It has been accepted for inclusion in Classical Studies: Faculty Publications and Other Works by an authorized administrator of Loyola eCommons. For more information, please contact ecommons@luc.edu. (c) (i) $\Theta$

This work is licensed under a Creative Commons Attribution-Noncommercial-No Derivative Works 3.0 License. (c) Classical Association of the Atlantic States, 1982. 


\section{PAPYROLOGY AND ROMAN HISTORY: 1956-1980}

The papyri of the Roman Empire have not yet been subjected to the kinds of systematic scholarly enterprises to which the Ptolemaic papyri have been subjected. There is, for example, no comprehensive prosopography comparable to the Prosopographia Ptolemaica, and it is, I think, senseless to start one. What the student of the Roman imperial period has at his disposal is lists of assorted of ficials, functionaries, and military personnel. Among those compiled in the generation under discussion (1956-1980) there may be mentioned, by way of example, Bureth's collection of imperial titulatures; Mussies' supplement to Henne's 1935 listing of nome strategi; Reinmuth's list of Egypt's prefects; Sijpesteijn's list of gymnasiarchs; Vandoni's list of epistrategi, Bastianini's of the strategi of the Arsinoite nome, and Devijver's of Roman cavalry officers originating from or stationed in Egypt; Cavenaile's and Criniti's lists of Roman soldiers in Egypt.' These lists, like so many other efforts in the study of the Roman Egyptian papyri, though retaining their utility for many years, often also seem outdated shortly after if not by the time of their appearance. New papyri provide new names or greater chronological precision; older known texts are revised, their dates are corrected, the names they carry are amended. In a familiar papyrological pastime, "ghost names" are hunted, caught, and deleted from their respective fasti. The process of refinement is endless. ${ }^{2}$

One reason why the lists become outdated so quickly, why personallyowned copies soon become full of marginal annotation, why comprehensive projects are not lightly if at all undertaken, is that for the Romandate papyri (except for a few of the World War II years) there has been no lull in publication for want of material, as there has been for the Ptolemaic papyri; no lull owing to lack of interest in the face of countless

$1 \mathrm{P}$. Bureth, Les titulatures impériales dans les papyrus, les ostraca et les inscriptions d'Égypte (30 a.C. - 284 p.C.) (Brussels 1964: Pap. Brux. 2); G. Mussies, Supplément à la liste des stratèges des nomes égyptiens de H. Henne (Leiden 1965: Papyrologica LugdunoBatava XIV); O. W. Reinmuth, "A Working List of the Prefects of Egypt, 30 B.C. 10299 A.D.," BASP 4 (1967) 75-128, revised by G. Bastianini, ZPE 17 (1975) 263-328; P. J. Sijpesteijn, Liste des gymnasiarques des métropoles de l'Égypte romaine (Amsterdam 1967); M. Vandoni, Gli epistrategi nell'Egitto greco-romano (Milan 1971: Testi e documenti per lo studio dell'antichità 33); G. Bastianini, Gli strateghi dell'Arsinoites (Brussels 1972: Pap. Brux. 11); H. Devijver, De Aegypto et Exercitu Romano sive Prosopographia Militiarum Equestrium quae ab Augusto ad Gallienum seu statione seu origine ad Aegyptum pertinebant (Louvain 1975: Studia Hellenistica $: \rightarrow$ R. Cavenaile, Aegyptus 50 (1970) 213-320 and N. Cri1 $\rightarrow$ Aegyptus 53 (1973) 93-158 (list and supplementary list of Roman soldiers in Egypt). Cf. Devijver, "The Roman Army in Egypt (with Special References to the Militiae Equestres)," $A N R W$ II.1 (Berlin/New York 1974) 452-92. Another important list (not restricted to the Roman period): Giulia Ronchi, Lexicon theonymon rerumque sacrarum et divinarum ad Aegyptum pertinentium (Milan 1974: Testi e documenti per lo studio dell'antichita 45). See also J. E. G. Whitehorne's recent listing of Oxyrhynchite strategi in ZPE 29 (1978) 167-89.

2 For two, among many, examples: A. K. Bowman, "Aurelius Mercurius-A 'Ghosl' Prefect?", BASP 6 (1969) 35-40; P. J. Parsons, "M. Aurelius Zeno Januarius," Proceedings of the Twelfth International Congress of Papyrology (Toronto 1970: Amer. Stud. Pap. 7) 389-97. 
papyri, as there has been for the Byzantine period. Thus there has not been, and in the foreseeable future there will not be, the kind of pause in which a grand synthesis is supposedly most comfortably created; and so, for Roman Egypt there is no synthesis on the scale of those which Préaux and Rostovtzeff have created for Ptolemaic Egypt. There are, however, some basic large-scale older studies-Oertel's on liturgies, Lesquier's on the Roman army in Egypt, Wallace's on taxation, to name a few. ${ }^{3}$ For their topics substantially more evidence is now available. Recent studies (especially Lewis' on liturgies) ${ }^{4}$ have with this evidence refined the details of the venerable older works, but the older works, though outdated, remain fundamental; they are yet to be replaced. The last few years have also seen new monographs, some the outgrowths of doctoral dissertations, on other topics-Swarney's on the idios logos, Bowman's on town councils, Parássoglou's on imperial estates, Talamanca's on the prefect's conventus - but surely the most unusual and possibly the most important single book produced in the years 1956-1980 is the late Professor Braunert's Die Binnenwanderung, a massive study on social mobility in Ptolemaic and Roman Egypt as manifested in evidence for population movements from place to place within Egypt. ${ }^{5}$

To pass on (with unfortunate abruptness) from papyrological monographs and other secondary studies to the papyri themselves, I think that the single most pleasing historical find that has appeared in the past twenty-five years is the Cologne papyrus containing part of a Greek version of Augustus' funeral oration for Marcus Agrippa. Published with rich commentary in 1970 by Ludwig Koenen, the fragment gave rise to immediate further discussion on Agrippa's marriages and family, and on the type of imperium conferred on him by Augustus. Two very recent articles, by Haslam (1979) and Badian (1980), have brought further refinement to the exercise, initiated by Koenen, of backtranslating the text from Greek to Latin so as to attempt to recover the ipsissima verba spoken by the emperor himself. The papyrus is important for $\mathrm{W}$. Kierdorf's new monograph on the laudatio funebris ${ }^{6}$

3 Fr. Oertel, Die Liturgie. Studien zur ptolemaischen und kaiserlichen Verwaltung Ägyptens (Leipzig 1917); J. Lesquier, L'armée romaine d'Égypte d'Auguste à Dioclétien (Cairo 1918: Mém. IFAO 41); S. L. Wallace, Taxation in Egypt from Augustus to Diocletian (Princeton 1938).

4 See N. Lewis, Inventory of Compulsory Services (Toronto 1968: Amer. Stud. Pap. 3). There is a recent bibliography of Professor Lewis' writings, many of them on liturgies, in BASP 15 (1978) 2-8. A new edition of the Inventory is expected soon.

5 P. R. Swarney, The Plolemaic and Roman Idios Logos (Toronto 1970: Amer. Stud. Pap. 8); A. K. Bowman, The Town Councils of Roman Egypt (Toronto 1971: Amer. Stud. Pap. 11); G. M. Parássoglou, Imperial Estates in Roman Egypt (Amsterdam 1978: Amer. Stud. Pap. 18); G. F. Talamanca, Ricerche sul processo nell'Egitto greco-romano 1: L'organizzazione del 'conventus' del 'Praefectus Aegypti' (Milan 1974); Horst Braunert, Die Binnenwanderung. Studien zur Sozialgeschichte Ägyptens in der Ptolemäer- und Kaiserzeit (Bonn 1964: Bonner Historische Forschungen 26).

6 Ed. pr.: L. Koenen, ZPE 5 (1970) 217-83. See also E. W. Gray, ZPE 6 (1970) 227-38; Koenen, ZPE 6 (1970) 239-43; M. W. Haslam, CJ 75 (1980) 193-99; E. Badian, CJ 76 (1980-81) 97-107; R. J. Sherk, ZPE 41 (1981) 67-69; W. Kierdorf, Die Laudatio Funebris. Interpretationen und Untersuchungen zur Entwicklung der römischen Leichenrede (Meisenheim 1980: Beitr. Kl. Phil. 106). 
At the other end of the chronological spectrum traditionally assigned to Roman Egypt are to be found the Beatty Panopolis papyri published by Skeat in 1964, two lengthy rolls (later remade into a codex for other purposes) "containing official correspondence of the Strategus of the Panopolite nome, and dating from A.D. 298 and A.D. 300 respectively." These documents are very important, as many will know, for the history of the Roman army in Egypt; they are significant also because they concern preparations for an impending visit by Diocletian, and because at publication they prefigured (as we know now from hindsight) the many late third/early fourth century papyri that the hitherto quiet provenance of Panopolis would come to yield.?

For reigns between Augustus and Diocletian there are scattered additional highlights published between 1956 and 1980, too numerous for all to receive specific mention: more fragmentary reports of proceedings that anticipate or belong to the "Acts of the Alexandrians" series; a new fragment of the Gnomon of the Idios Logos; a letter of Nero refusing divine honors and remitting crown gold to the Arsinoite Greeks; a private letter that gives a precise date and time for Titus' entry into Alexandria while en route to Rome on the conclusion of the Jewish War; more evidence, both from Egypt and from the Dead Sea caves, on the Jewish revolts of the second century. ${ }^{8} \mathrm{~S}$. Omar's publication of the papers of the Soterichos archive brings with it substantial new information on viticulture in Egypt and the earliest papyrus attestation for Vespasian (5 August 69), the month following his acclamation. Alan Bowman has argued, and most scholars now concur, that an Oxyrhynchus papyrus, published in $J E A$ in 1966 and previously identified as a letter of Severus Alexander, of Maximinus, or of Vaballathus, most likely was issued by Avidius Cassius at the beginning of his revolt in A.D. $175 .{ }^{9}$ Other papyri provide additional information on the damnationes memoriae of emperors and members of their families. Partially despite, partially be-

7 T. C. Skeat, Papyri from Panopolis in the Chester Beatty Library (Dublin 1964: Chester Beatty Monographs No. 10). Importance of these papyri for military questions: see the recent articles by A. K. Bowman, "The Military Occupation of Upper Egypt in the Reign of Diocletian," BASP 15 (1978) 25-38; R. P. Duncan-Jones, "Pay and Numbers in Diocletian's Army," Chiron 8 (1978) 541-60; R. MacMullen, "How Big Was the Roman Imperial Army?", Klio 62 (1980) 451-60. More on Panopolis as a provenance below, p. 7.

8 P. Oxy. XLII 3019-3023 (texts related to Acta Alexandrinorum): cf. D. Hennig, Chiron 5 (1975) 317-35; see also J. C. Shelton, "A Fictitious Edict of Caracalla?", ZPE 39 (1980) 179-82, regarding $P$. Bon. 15 in particular but also suggesting there may be other inauthentic documents "lurking in our editions and accepted as genuine." Gnomon fragment: P. Oxy. XLII 3014. Nero's letter: O. Montevecchi, in Aegyptus 50 (1970) 3-33. Titus' entry into Alexandria: P. Oxy. XXXIV 2725; cf. further discussion by M. C. J. Miller, "A New Record of Titus' Return to Alexandria after the Sack of Jerusalem (April 25, A.D. 71)," The Ancient World 1 (1978) 137-40. Jewish revolts: A. Fuks, "Aspects of the Jewish Revolt in A.D. 115-17,' JRS 51 (1961) 98ff; C. P. Jud. II, pp. 225ff. and papyri nos. 435450; A. Swiderek, JJP 16-17 (1971) 45-46; BGU XI 2085; Y. Yadin, Bar-Kokhba (New York 1971).

9 S. Omar, Das Archiv des Soterichos (Opladen 1979: Papyrol. Colon. 8). A. K. Bowman, "A Letter of Avidius Cassius?", JRS 60 (1970) 20-26. 
cause of the recent evidence, Geta, Caracalla's younger brother, remains the name most frequently cancelled in the papyri. ${ }^{10}$ Finally, with his "corn-dole archive", P. Oxy. XL, John Rea has clarified with painstaking care the chronology of the reigns of Aurelian and of those emperors who preceded and followed him. Further, through his analysis of the working of the dole system in the provincial city of Oxyrhynchus in the late third century, he has shed light on the system's working in the imperial capital itself in earlier times. "I

It is natural that archives like the Oxyrhynchus corn dole archive, and papyri like the Cologne funeral oration fragment and some of the other papyri just mentioned, should, because they concern the Empire as a whole, work themselves immediately into the historiographical mainstream. At the same time it is true that the vast majority of published papyri, new and old, are of decidedly pedestrian character and local import-land leases, loans, dike certificates, poll-tax receipts, etc.-and often too fragmentary to be of much use. The publication of such pieces was defended some time ago by Professor Youtie, in a gentle review of a remarkably undistinguished volume of Greek papyri, both with his own considerable eloquence and with an extensive quotation: Renan's wellknown figure of philologists as ants, each carrying his little bit toward the construction of an edifice whose general design he does not know. ${ }^{12}$ The papyrologist may be happy to agree; the historian may be inclined to doubt. Much of the evidence that the Fayum region of Egypt continues to produce, especially that which dates to the second century, seems to be very "tired". It may bring fresh prosopographical, chronological and topographical detail, but nothing in the way of new document types, little in the way of intrinsically interesting texts. These are the kinds of papyri important historically not so much for themselves as for what, en masse, they have to tell us about a system (for example, the collection of customs dues at points of Fayum entry and egress, the maintenance of the dikes), or about agrarian practices (for example, standard and variant land-leasing terms), or about a specific Fayum family or village. ${ }^{13}$ These are the kinds of papyri that require re-collection, arrangement, analytic commentary and discussion before, with their usually provincial

\footnotetext{
10 Recent examples and bibliography: Bowman, JRS 66 (1976) 156. See in particular $B G U$ XI 2056; $P$. Oxy. XLI 2955 and XLV 3244; cf. Sijpesteijn, ZPE 13 (1974) 219-27; Koenen, ibid. 228-39. See also J. C. Shelton, ZPE 6 (1970) 90 (Geta's name cancelled in a receipt for the 10\% tax on sacrificial calves, A.D. 209); C. A. Nelson, ZPE 9 (1972) 258 and inn. 9-10; P. Mertens, "La damnatio memoriae de Geta dans les papyrus," Coll. Latomus 44 (1960) $541-52$.

11 See also E. G. Turner, "Oxyrhynchus and Rome," HSCP 79 (1975) 1-24, esp. $16 \mathrm{ff}$.

12 H. C. Youtie, review reprinted in his Scriptiunculae (Amsterdam 1973) II, 851-53. The image of the philologist as a laborer who is unaware of his building's general design is also to be found in Renan's memorial minute for the scholar who preceded him in the chair of Hebrew at the Collège de France, Étienne Quatremère; cf. E. W. Said, Orientalism (Vintage Books edn., New York 1979) 139 and 338 n. 39.

13 Systems: M. Hombert and C. Préaux's study of the Roman Egyptian quadrodecennial census (Leiden 1952) falls outside the chronological scope of this paper. For an example, however, see P. J. Sijpesteijn, Penthemeros-Certificates in Graeco-Roman Egypt (Leiden 1964: Papyrologica Lugduno-Batava XII).
} 
embrace, they are subsumed into the general historical mainstream. For such Fayum evidence the most important recent work is, I think, that which focuses on the social and economic history of particular villages (John Oates' and Ann Hanson's work on Philadelphia, its landholding patterns, citizenship ratios and economic woes, real or alleged; Deborah Samuel's studies, past and in progress, on Soknopaiou Nesos) $;{ }^{14}$ and that which aims to reconstitute and republish or discuss dispersed Fayum family archives (e.g., Foraboschi's republication of the Kronion papers; Whitney Bagnall's Duke dissertation on the Laches archive). ${ }^{\text {is }}$

As for much of the recent evidence from Oxyrhynchus, a thumbing through of the latest $P$. Oxy. volumes suggests that although occasional gems are sprinkled throughout the first three Roman imperial centuries, the most substantial recent gains belong to the third and fourth centuries, providing more information on the Oxyrhynchus town council, its membership and operation, more information on such pivotal fourth-century municipal of ficials as the curator civitatis. ${ }^{16}$ This is a trend in papyrology and Roman historical studies that I suspect will continue, along with some others which merit our attention. I note four striking trends (no doubt there are more) which seem to me to be well under way and which show promise of continuing over the next two decades at least.

1. First, a widening of papyrology's geographical scope. At the beginnings of papyrology in the nineteenth century and for most of its earlier history (if the Herculaneum finds are discounted), there was an almost unbroken bond between papyrology the science and Egypt the land that produced the texts on which the papyrologists labored. Both had to be taken together or not at all; and even Egypt, because Alexandria produced no papyri and the Delta region was so poorly represented, had tacitly to be understood as "Egypt above Memphis". The discovery near Avroman, Kurdistan (close to the Turkish border), in or about 1909, of three parchment documents of Parthian date may have hinted at greater things to come, ${ }^{17}$ but these hints were not realized until nearly twenty

14 Cf., e.g., J. F. Oates, "The Evidence of Egypt," BASP 2 (1965) 57-65; "Philadelphia in the Fayum during the Roman Period," Atti dell'XI Congresso internazionale di papirologia (Milan 1966) 451-74; "Fugitives from Philadelphia," Essays in Honor of C. Bradford Welles (New Haven 1966: Amer. Stud. Pap. 1) 87-95; "Landholding in Philadelphia in the Fayum (A.D. 216)," Proc. Twelfth Int. Congr. Papyrology, 385-87; "Census Totals: Nemesion's Notes," Collectanea Papyrologica I (Bonn 1976: PTA 19) 189-96. Ann E. Hanson, "List of Taxpayers from Philadelphia," ZPE 15 (1974) 229-48; “Aspects of the Reign of Gaius in the Philadelphia Papyri," XVI International Congress of Papyrology Proceedings (Chico, CA 1981) 345-55. Deborah H. Samuel, "Taxation at Socnopaiou Nesos in the Early Third Century," BASP 14 (1977) 161-207; "Greeks and Romans at Socnopaiou Nesos," XVI Congress Proceedings, 389-403.

15 D. Foraboschi, L'archivio di Kronion (Milan 1971). Whitney Scofield Bagnall, The Archive of Laches (Diss. Duke University 1974); cf. eadem, "Some Prosopographical Observations on the Laches Archive," BASP 10 (1973) 65-70.

16 The Oxyrhynchus town council: e.g., P. Oxy. XLV 3244-3249. For the curator civitatis: e.g., P. Oxy. XLVI 3305-3311.

17 E. H. Minns, "Parchments of the Parthian Period from Avroman in Kurdistan," JHS 35 (1915) 22-65. 
years later with the remarkable finds at Dura-Europos-on-theEuphrates..$^{18}$ It is of course the military content of many of the Dura documents, the papers of the Twentieth Palmyrene Cohort, that give these papyri so much of their interest; but clearly contributing to that interest is the fact that their provenance was not Egypt. In the period under consideration (1956-1980), the most significant increment to Greek papyri of non-Egyptian provenance is owed to the discoveries by the Israelis excavating the now famous Cave of Letters at Engedi in 1960 and 1961: Greek, Hebrew and Aramaic documents of the Bar-Kochba revolt; Nabataean, Aramaic and Greek documents belonging to the archive of Babata, a lady who may herself have perished in the revolt. ${ }^{19}$

In addition to papyri discovered outside Egypt, it is worth noting in passing the rare papyri of Egyptian provenance which were drawn up outside Egypt and imported. It is probably not accidental that several of these are records of slave sales; a recent important example is the Oxyrhynchus papyrus published by John Oates in 1969 recording a slave sale concluded on the island of Rhodes in the reign of Gordian III (238244). ${ }^{20}$

Even within Egypt new provenances are coming into play and adding to the geographical diversity of the sites from which papyri are being recovered. Panopolis (Achmîm) has already been mentioned as a newly important source of late third and early fourth century papyri; these have been acquired by purchase, the majority now being owned by the Institut für Altertumskunde of the University of Cologne and a substantial number by Duke University. There are some in Berlin. Many have been published, especially in $Z P E$; some are in preparation, more may be expected. ${ }^{21}$ Excavations by the Oriental Institute of the University of Chicago now in progress at Quseir on the Red Sea coast have produced papyrus scraps, some in Latin, about which Roger Bagnall has published

18 See now Clark Hopkins' recent popular account of the manuscript and other discoveries at Dura: The Discovery of Dura-Europos (New Haven/London 1979). The Dura military papyri have been re-edited by R. Fink, Roman Military Records on Papyrus (Cleveland 1971: American Philological Association Monographs 26). Cf. R. Cavenaile, Corpus Papyrorum Latinarum (Wiesbaden 1958), nos. 324-345.

19 Y. Yadin, Bar-Kokhba (New York 1971). Most of the earlier Greek (and two Latin) Dead Sea finds are published in Discoveries in the Judaean Desert II (Oxford 1961).

20 An earlier listing of papyri (and parchments) either found outside of Egypt or written outside Egypt and imported: R. Taubenschlag, Opera minora II (Warsaw 1959) 29-43. J. F. Oates, "A Rhodian Auction Sale of a Slave Girl," JEA 55 (1969) 191-210. The most recently published of such slave sales, from Side in Pamphylia, is to be found in $P$. Turner (see no. 22).

21 The Cologne Panopolis papyri (P. Köln Panop.): preliminary description by D. Hagedorn, "Papyri aus Panopolis in der Kölner Sammlung," Proc. Twelfth Int. Congr. Papyrology, 207-11; publication by D. Hagedorn, H. C. and L. C. Youtie in ZPE 7 (1971) 1-40; 8 (1971) 207-34; 10 (1973) 101-70. See also G. M. Browne, "Harpocration Panegyrista," ICS 2 (1977) 184-96; P. Coll. Youtie II 71-73. Duke Panopolis papyri: W. H. Willis, "Two Literary Papyri in an Archive from Panopolis," ICS 3 (1978) 140-53. Berlin Panopolis papyri: Z. Borkowski, Une description topographique des immeubles à Panopolis (Warsaw 1975). 
preliminary information. ${ }^{22}$ Since 1963 the Egypt Exploration Society has been excavating at Qasr Ibrim (ancient Premnis), a site in Egyptian Nubia 150 miles south of Aswan and once thought to be in danger of submersion by Lake Nasser. Most of the textual finds are late, written in Coptic, Nubian, Arabic and other languages. They will be useful mainly for filling in the void of medieval and early modern Nubian history. The site has, however, also yielded some earlier Greek and Latin papyri (including the much discussed Gallus fragment) ${ }^{23}$ of the late first century B.C./early first century A.D., whose presence has been linked (at least the link has been suggested) to the Roman occupation of Egyptian Nubia under Petronius, circa 23-21 B.C. ${ }^{24}$ The Greek fragments so far published have not been very promising ${ }^{25}$; but there does seem to be sound reason to hope for the future. My understanding is that the textual finds from the Qasr Ibrim excavations have been so numerous as to prevent even preliminary cataloguing on the site. Finally, there has just appeared the publication of the cartonnage from the leather covers of the Nag Hammadi codices, begun by the late J.W.B. Barns and completed by John Shelton and Gerald Browne-153 Greek texts, 19 Coptic, all of fourth-century date. ${ }^{26}$

2. A second trend, which may be paired with, because it contributes to, the first trend just discussed, is what I perceive as renewed attention to what Roger Bagnall has just called "that often-despised source, ostraka." Bagnall is himself one in the vanguard of that movement, having shared in the editing of the ostraka of the Royal Museum of Ontario (1971) and in the work of extracting statistics on longevity and taxation from them. ${ }^{27}$ More recently, his Florida ostraka, together with some Amsterdam ostraka, have provided opportunities for discussing Roman army and police duty in Upper Egypt, especially with respect to garrison duties at strategic communication points in the Eastern Desert. ${ }^{28}$

Ostraka often survive in locales where papyri have not, and therefore can sometimes, though often in less satisfactory fashion, fill in gaps left

22 See now Quseir al-Quadim 1978: Preliminary Report, ed. D. S. Whitcomb and J. H. Johnson (Cairo 1979) 243-44.

${ }^{23} \mathrm{Ed}$. pr. of the Gallus fragment: R. S. Anderson, P. J. Parsons and R. G. M. Nisbet, JRS 69 (1979) 125-55.

24 Preliminary reports of the excavations in $J E A$ volumes, beginning with 50 (1964). Cf. W. Y. Adams, "The Excavations at Qasr Ibrim," ARCE Annual Meeting Abstracts (Boston 1981) 21 and other paper synopses among those Abstracts; the abstract of Adams' AlA paper in $A J A 85$ (1981) 184.

25 M. E. Weinstein and E. G. Turner, JEA 62 (1976) 115-30.

26 Nag Hammadi Codices: Greek and Coptic Papyri from the Cartonnage of the Covers (Leiden 1981: Nag Hammadi Studies 16).

27 A. E. Samuel, W. K. Hastings, A. K. Bowman, R. S. Bagnall, Death and Taxes: Ostraka in the Royal Ontario Museum (Amsterdam 1971: Amer. Stud. Pap. 10).

28 R. S. Bagnall, The Florida Ostraka: Documents from the Roman Army in Upper Egypt (Durham, NC 1976: Greek, Roman and Byzantine Monograph 7); reviews by Keenan, BASP 15 (1978) 281-83, and Van Rengen, Cd'E 54 (1979) 332-36. See also Bagnall, "The Roman Garrison of Latopolis," BASP 12 (1975) 135-44, and "Army and Police in Roman Upper Egypt,' JARCE 14 (1977) 67-86; R. S. Bagnall, P. J. Sijpesteijn, and K. A. Worp, Ostraka in Amsterdam Collections (Zutphen 1976: Studia Amst. 9); R. Coles, "The Barns Ostraka,"' ZPE 39 (1980) 126-31. 
by the papyri. The Theban area is the richest source of Egypt's ostraka. Outside Egypt, it is worth mentioning the ostraka excavated by the French at Bu Njem (in ancient Tripolitania) in the early 1970s..$^{29}$ These are of third-century date, written in Latin, and like most of the Florida and some of the Amsterdam ostraka are concerned with military matters. Moreover, papyrologists have worked, or are working, on documents written on still other materials, activities which contribute to an extension of the old papyrological geographical horizons. There is the work of Alan Bowman and David Thomas on the wooden tablets unearthed in 1973 and 1974 at Vindolanda in Northumberland, a mile from Hadrian's wall. ${ }^{30}$ Written in Latin between A.D. 85 and 120, most of the tablets pertain in some way to members of a Roman military unit; most are "official camp records of the unit" or "private papers of individual soldiers belonging to the unit." Timothy Renner has undertaken a renewed study of the Campanian wooden tablets, discovered in 1959 and published piecemeal beginning in the 1960s; these are business documents, two in Greek, the rest in Latin, dating between A.D. 29 and $61 .{ }^{31}$

The third and fourth trends, like the first and second, are conveniently paired. The first and second fit together well because of their overlapping geographical concern, the third and fourth because of their conjoined concern for the general configuration of Roman Egyptian history.

3. The third trend is that the lines of continuity from Ptolemaic to Roman Egypt have come under question. There is a growing sense that the changes effected by the Roman takeover have been underestimated and, hand in hand with that view, that Egypt's status within the empire may not have been so special after all. The pivotal statement is Professor Naphtali Lewis's essay "Greco-Roman Egypt: Fact or Fiction?", an address delivered in 1968 in Ann Arbor and published in 1970. ${ }^{32}$ Some additional details have been worked out, for example, by Parássoglou in his monograph on imperial estates. John Rea's work on the Oxyrhynchus corn dole archive would also tend to support the similarities rather than the differences between Egypt and the rest of the Empire. But, as Ludwig Koenen reminds me, continuity or discontinuity is now "a very hot issue"; it is likely to remain so for some time.

29 Preliminary description and discussion: R. Rebuffat and R. Marichal, REL 51 (1973) 281-86.

30) General description: A. K. Bowman and J. D. Thomas, The Vindolanda Writing Tablets (Newcastle upon Tyne $19^{\circ} \rightarrow$. Bowman and Thomas, Historia 24 (1975) 463-78.

31 Preliminary informal report by Renner given to the American Society of Papyrologists, meeting in New Orleans, 29 December 1980. The tablets were discovered at Agro Murecine near Pompeii and are sometimes referred to as the "New Pompeii Tablets" to distinguish them from the tablets found in the last century in Pompeii in the house of $\mathrm{L}$. Caecilius Secundus. Editiones principes in RAAN 41 (1966) 107ff.; 43 (1968) 195ff.; 45 (1970) $211 \mathrm{ff}$.; 46 (1971) 173ff. and 183ff.; 47 (1972) 307ff. and 311ff.; 51 (1976) 145ff.; 53 (1978) 249ff.; $A A N 88$ (1977) I2lff.; $A A P$, n.s. 29 (1980) 175ff. Emendations: see esp. L. Bove, RAAN 44 (1969) 25ff.; 47 (1972) 167ff.; and J. G. Wolf, SDHI 45 (1979) 14lff. I am deeply grateful to Dr. Renner for sending me (letter of 24 May 1981) bibliographical details and additional information on these tablets.

32 N. Lewis, "Greco-Roman Egypt: Fact or Fiction?", Proc. Twelfih Int. Congr. Papyrology, 3-14. 
4. Egypt's so-called Sonderstellung has traditionally been less an issue with historians of the late Roman period than with historians of the early imperial period because it was believed that Diocletian was responsible for rationalizing the imperial system, for tempering Egypt's peculiar status and making that land conform to administrative patterns existing elsewhere in the empire. This brings me to my fourth trend, which is that the "periodizing" of Roman Egyptian history is currently undergoing revision. The work of Bowman, Thomas, and others, clarifying the details and chronology of the Diocletianic reforms in too many particulars to be discussed here, has made the year 284 , the traditional divide between Roman and Byzantine Egypt, even more unacceptably artificial than it was; Bowman labels it "absurd." ${ }_{33}$ It seems to me now that with the vestigial significance of 284 removed, the third and fourth centuries together form a convenient period for the study of Roman Egyptian history. In much the same way, the two preceding and two following centuries may be taken together in pairs as convenient temporal units for study. I am not, however, proposing an ironclad system of three double centuries, or ruling out the possibility of a future reshuffling if evidence and study suggest it; but for now it is this breakdown that seems in fact if not in theory to be in operation.

I close briefly by pointing to what may be the first massive systematic scholarly attack on the papyri of Roman Egypt (and Ptolemaic and Byzantine Egypt), a Milan project to republish all Greek documents according to type. This project, called the Corpora Papyrorum Graecarum, was announced in 1977 in Brussels at the XV International Congress of Papyrology. Finally, what $I$ have presented above is only a selection of the material and a personal view of the general situation. For a rich, annotated bibliography, covering the results of scholarship especially, but far from exclusively, from 1960 to 1975, one should refer to Alan Bowman's article in JRS 66 (1976) 153-173: "Papyri and Roman Imperial History." Supplementary notes may be found in the new (1980) edition of Eric Turner's Greek Papyri: An Introduction. ${ }^{34}$

\section{Loyola University of Chicago}

JAMES G. KEENAN

\footnotetext{
33 From among various articles, see Bowman, "Some Aspects of the Reform of Diocletian in Egypt," Akten des XIII. Internationalen Papyrologenkongresses (Munich 1974: Münch. Beitr. 66) 43-51; Thomas, "The Disappearance of the Dekaprotoi in Egypt," $B A S P 11$ (1974) 60-68; "The Date of the Revolt of L. Domitius Domitianus," ZPE 22 (1976) 253-79; "A Family Dispute from Karanis and the Revolt of Domitius Domitianus," ZPE 24 (1977) 233-43; "Epigraphai and Indictions in the Reign of Diocletian," BASP 15 (1978) 133-45. $\rightarrow$ Roger S. Bagnall, "The Number and the Term of the Dekaprotoi," Aegyptus 58 (1978) 160-67.

34 This paper was presented on 8 May 1981 at a panel on "Papyrology and Ancient History" during a meeting of the Association of Ancient Historians in Ann Arbor. It followed Roger Bagnall's paper, which is also published in the present journal. Like Bagnall's paper, it was originally intended only for oral presentation and is printed here in response to requests made at the meeting. The text is almost precisely that which was delivered; pertinent notes have been slightly expanded. I can but heartily second the thanks extended by Professor Bagnall to Professors Eadie, Starr and Koenen of the University of Michigan.
} 